\section{p-ISSN 2476-9886 \\ e-ISSN 2477-0302 \\ J.Edu}

Volume 4 Nomor 1, April 2018, HIm 48-54

\section{Jurnal EDUCATIO}

Jurnal Pendidikan Indonesia

DOI: https://doi.org/10.29210/120182137

Akses Online :

http://jurnal.iicet.org

Dipublikasikan oleh :

Indonesian Institute for Counseling, Education and Therapy (IICET)

Info Artikel:

Diterima: 11/03/2018

Direvisi: 23/03/2018

Dipublikasikan: 15/04/2018

\title{
PERMAINAN BOLA BERANTAI UNTUK PENINGKATAN HASIL BELAJAR BOLA VOLI PADA SISWA KELAS IV SDN 12 API - API KECAMATAN BAYANG KABUPATEN PESISIR SELATAN
}

\begin{abstract}
Kasmirman $^{1}$
${ }^{1}$ SDN 12 Api - Api

Abstract

The purpose of this research is to know the learning result of passing through the volley ball through game with the ball of the chain at the fourth-grade student of SDN 12 Api - Api Kec. Bayang. The sample of research is 24 people. The type of research used is classroom action research (PTK). The results showed an increase in student learning outcomes.
\end{abstract}

Keyword: learning outcomes, volley ball, chain ball

(c) (i) This is an open access article distributed under the Creative Commons Attribution License, which permits unrestricted use, distribution, and reproduction in any medium, provided the original work is properly cited. C2017 by author and Indonesian Counselor Association (IKI).

\section{PENDAHULUAN}

Pendidikan jasmani merupakan bagian yang terpenting dari proses secara keseluruhan yang pola pencapaian tujuannya menggunakan aktivitas jasmani sedangkan sasaran tujuan jasmani yang ingin dicapai meliputi tujuan dari segi kognitif, afektif, dan psikomotor. Kognitif dapat diartikan sebagai aspek yang meliputi fungsi intelektual seperti pemahaman, pengetahuan dan kemampuan berfikir. Afektif dapat diartikan sebagai aspek yang menyangkut perasaan, moral dan emosi (kemampuan menerima,menanggapi, dan berkeyakinan). Psikomotor dapat diartikan sebagai aspek yang menyangkut ketrampilan motorik seperti gerak tubuh, perilaku bicara. Tujuan jasmani berarti meliputi kesehatan fisik dan psikis (terhindar dari stress (Zola, N., Fadli, R. P., \& Ifdil, I., 2017; Taufik, T., \& Ifdil, I., 2013; Barseli, M., \& Ifdil, I., 2017) dan depresi). Melihat pendidikan jasmani baik dari segi pola pencapaian tujuan maupun tujuan yang ingin dicapai maka perlu peninjauan yang lebih mendalam tentang pendidikan jasmani supaya nantinya tujuan pendidikan jasmani tersebut benar-benar memenuhi sasaran.

Sesuai dengan tujuan pendidikan jasmani maka faktor anak didik (siswa) merupakan faktor yang dijadikan obyek didalam pelaksanaan proses belajar mengajar pendidikan jasmani. Guru mempunyai peranan sangat besar 
dalam pencapaian keberhasilan anak didik (siswa) dalam proses belajar, dimana seorang guru tidak hanya mampu mendidik saja tetapi guru dituntut mampu sebagai fasilitator, motifator, dan juga sebagai pembaharuan dalam proses belajar mengajar. Selain itu seorang guru pada tingkat sekolah dasar ditutuntu untuk memenui kebutuhan setiap anak dimana kerateristik fisik, metal, sosialnya berbeda antara anak didik (siswa) satu dengan anak didik (siswa) yang lainnya. Oleh karena itu, guru pendidikan jasmani dituntut untuk mengetahui dan memahami serta mampu melaksanakan beban tugas mendidik dan mengajar dalam proses belajar mengajar pendidikan jasmani.

Proses belajar mengajar pendidikan jasmani, perlu mengetahui bagaimana sebenarnya pembelajaran itu berlangsung dan seorang guru di tuntut untuk mengetahui pengetahuan, ketrampilan dan sikap yang profesional dalam membelajarkan siswa. Dalam pembelajaran keberhasilan siswa tidak hanya ditentukan oleh hasil pembelajarannya akan tetapi juga di pengaruhi oleh proses belajar mengajarnya, apabila dalam pembelajaran, proses pembelajaran baik maka pencapaian hasil yang di harapkan akan tercapai, maka dari itu guru harus benarbenar mempersiapkan materi yang akan diajarkan sebelum melakukan pembelajaran agar dapat melaksanakan tugas profesinya dengan baik.

Guru didalam melaksanakan tugas profesinya dihadapkan pada berbagai tantangan seperti bagaimana cara bertindak atau bersikap yang tepat, apa bahan belajar yang paling sesuai, apa metode penyajian yang paling efektif, permaianan apa yang bisa dipakai, apa langkah-langkah yang paling efisien, sumber belajar mana yang bisa diakses dan bagaimana sistem evaluasi yang dapat mengukur ketercapaian tujuan pembelajaran. Oleh karena itu, guru harus kreatif dalam memodifikasi pembelajaran agar siswa minat atau tidak bosan dalam melaksanakan pembelajaran agar tujuan pembelajaran tercapai. Seorang guru harus memiliki ide dalam setiap pembelajaran yang sesuai dengan kondisi yang ada, agar tujuan yang telah ditetapkan dapat tercapai dengan baik.

Pembelajaran yang terjadi selama ini, khususnya dalam pembelajaran bola voli adalah pembelajaran yang hanya memfokuskan pada gerak dasar dan tidak memperhatikan permainan apa yang dapat diterapkan. Oleh karena itu siswa akan cepat bosan dalam menerima pembelajaran. Dunia anak lebih dekat dengan situasi permainan dari pada yang serius, di dalam pembelajaran disajikan banyak variasi-variasi atau modifikasimodifikasi agar tidak mudah jenuh sebab siswa kerap kali juga cepat bosan melaksanakan kegiatannya (Djumidar, 2007: 11).

Berdasarkan permasalahan di atas, memodifikasi pembelajaran melalui permainan bola berantai dapat dijadikan alternatif dalam pembelajaran bola voli, khususnya dalam pembelajaran gerak dasar passing bawah. Sebagai langkah awal pembelajaran permainan bola voli kepada siswa yaitu di kenalkan macam-macam teknik dasar bola voli. Belajar macam-macam teknik dasar bola voli merupakan langkah awal yang harus dilakukan siswa untuk mencapai prestasi bolavoli.Macam-macam teknik dasar bolavoli tersebut harus dikuasai untuk mendukung penampilan seorang pemain, dan secara kolektif akan meningkatkan kualitas tim. Jika suatu tim para pemainnya menguasai macam-macam teknik dasar bola voli dengan baik, maka mempunyai peluang yang besar untuk memenangkan pertandingan.

Salah satu teknik dasar bola voli yang harus dikuasai terlebih dahulu dalam permainan bola voli adalah passing khususnya passing bawah. Hal ini karena, passing bawah memiliki tujuan untuk mengoperkan bola yang dimainkannya itu kepada teman seregunya untuk dimainkan dilapangan sendiri.Apabila penyajian bola dari passing bawah baik maka pengumpan bola (set-up) akan mudah melakukan serangan dan mendapatkan nilai.

Passing bawah merupakan salah satu teknik dasar bola voli yang paling mudah jika dibandingkan teknik lainnya. Namun tidak menutup kemungkinan bagi siswa sering melakukan kesalahan, sehingga kualitas passing bawah yang dihasilkan tidak sesuai yang diharapkan. Tidak jarang para siswa sekolah kurang mampu melakukan macam-macam bentuk passing bawah. Bahkan masih banyak diantara mereka yang belum mengetahui dan menguasai teknik passing bawah yang benar. Karena belum menguasai teknik dasar passing bawah maka masih banyak para siswa tidak mampu melakukan passing bawah dengan baik. Kendala atau masalah yang sering dihadapi siswa dalam proses belajar passing bawah, seorang guru harus mampu menganalisis dan mencari solusi yang tepat agar tujuan pembelajaran dapat tercapai dengan baik. Siswa yang belum mampu melakukan passing 
bawah disebabkan oleh beberapa faktor misalnya merasakan bola terlalu berat, terlalu besar ukurannya, permainan bola voli yang membosankan serta tidak memiliki minat untuk bermain bola voli. Untuk itu perlulah langkahlangkah yang tepat sesuai dengan kondisi siswa. Menurut Rijsdorp (1971:33) mengatakan bahwa,bagi anak bermain. Boleh saja mereka memainkan permainan bola voli, tetapi mereka akan bermain dengan caranya sendiri.

Memodifikasi bentuk pembelajaran (permainan) merupakan salah satu cara untuk mengatasi kesulitan dalam belajar passing bawah bola voli, jika permainan yang sesungguhnya dianggap sebagai kendalanya. Untuk memberi kemudahan dalam pembelajaran passing bawah bola voli dapat dilakukan dengan memodifikasi jenis permainan bola berantai. Pembelajaran passing bawah bola voli menggunakan modifikasi permainan yang digunakan merupakan cara untuk mengatasi kesulitan-kesulitan dan minat siswa dalam belajar passing bawah bola voli terutama pada siswa kelas IV SDN. 12 Api-Api Kec. Bayang.

SDN. 12 Api-Api adalah salah satu sekolah di Kec. Bayang, dimana dalam proses pembelajaran pendidikan jasmani Olahraga dan Kesehatn (PENJASORKES) pada siswa kelas IV SDN. 12 Api-Api Kec. Bayang masih terdapat beberapa kendala yang dihadapi siswa dalam melakukan olahraga pemanin bola voli, dimana siswa mengalami kesulitan dalam belajar passing bawah, siswa merasa takut mencoba karena merasa sulit melakukannya. Guru memberi contoh pasing bawah dengan menggunakan peralatan yang sebenarnya, menggunakan bola yang sebenarnya dan pemain yang sebenarnya, hal ini menyebabkan siswa kurang mampu, kesulitan malakukan passing bawah karena permainan bola voli yang sebenarnya sulit diterapkan menyebabkan anak cepat bosan. Sehingga hasil belajar maupun kemampuan passing bawah pada siswa kelas IV SDN. 12 ApiApi Kec. Bayang masih rendah, hal ini dibuktikan dari proses pembelajaran oleu Guru penjaskes di SDN. 12 ApiApi bahwa nilai hasil belajar passing bawah bola voli kurang memuaskan, banyak sekali siswa yang belum tuntas, nilai rata-ratanya di bawah nilai KKM (Kriteria Ketuntasan Minimal) yaitu 70. Bahkan hanya ada 13 siswa dari 24 siswa yang telah mencapai KKM. Sehingga hanya 54,17\% ketuntasan yang dicapai, padahal target ketuntasan yang akan dicapai adalah $80,00 \%$. Padahal passing bawah merupakan gerak paling dasar dalam permainan bola voli. Kesulitan-kesulitan yang dihadapi siswa dalam melakukan passing bawah menuntut guru untuk berkreativitas menerapkan pembelajaran yang tepat dalam menyampaikan materi pembelajaran. Misalnya dengan memodifikasi permainan. Berdasarkan latar belakang masalah seperti yang diuraikan diatas maka terlihat jelas bahwa kondisi tersebut menarik minat penulis untuk melakukan penelitian tindakan kelas dengan judul Permainan Bola Berantai Untuk Peningkatan Hasil Belajar voli pada Siswa Kelas IV SDN. 12 Api-Api Kec. Bayang

\section{METODOLOGI}

Penelitian ini dilaksanakan kepada siswa kelas IV SDN 12 Api-Api Kecamatan Bayang Kabupaten Pesisir Selatan Tahun ajaran 2016 / 2017. Denganjumlah sampel 24 orang, terdiri dari 14 orang siswa laki-laki dan 10 orang siswa perempuan. Teknik pengumpulan data dalam penelitian tindakan kelas (PTK) ini terdiri dari tes dan observasi. Tujuan yang ingin dicapai dalam penelitian ini adalah meningkatkan hasil belajar passing bawah bola voli siswa kelas IV SDN. 12 Api-Api Kec. Bayang. Adapun setiap tindakan upaya untuk pencapaian tujuan tersebut diranacang dalam satu unit sebagai satu siklus. Setiap siklus terdari empat tahap, yaitu: perencanaan tindakan, pelaksanaan tindakan, observasi dan interpretasi, analisis dan refleksi.

Intrumen yang digunakan dalam penelitian ini adalah 1) instrumen pembelajaran terditi dari silabus, rencana pelaksaan pembelajaran (RPP), dan lembar observasi 2) intrumen evaluasi meliputi aspek kognitif, aspek afektif, aspek psikomotorik. Analisis data menggunakan teknis analisa deskriptif kuantitatif.

\section{HASIL DAN PEMBAHASAN}

\section{1) Siklus I}

Pelaksanaan siklus I terdiri atas empat tahap yaitu perencanaan (planning), pelaksanaan tindakan (action), observasi, dan refleksi. Tahap-tahap yang dilaksanakan pada siklus I adalah sebagai berikut: 


\section{a. Perencanaan}

Perencanaan tindakan, sebagai berikut: (1) Peneliti melakukan analisis dalam silabus untuk mengetahui materi dan kompetensi dasar yang akan disampaikan kepada siswa dalam pembelajaran penjasorkes. (2) Membuat rencana pelaksanaan pembelajaran (RPP) dengan mengacu pada tindakan (treatment) yang diterapkan dalam PTK, yaitu passing bawah menggunakan bola plastik bergabus yang digantung untuk meningkatkan hasil belajar passing bawah bola voli. (3) Menyiapkan alat pembelajaran yang digunakan dalam proses pembelajaran passing bawah bola voli, yaitu: bola voli ukuran 4, bola plastik bergabus, rafia. (4) Menyusun instrument tes passing bawah bola voli dan lembar observasi atau pengamatan pembelajaran melalui rubrik penilaian yang tercantum pada RPP. (5) Peneliti dan kolaborator menentukan lokasi untuk melakukan tindakan yaitu di lapangan voli.

\section{b. Pelaksanaan}

Pelaksanaan tindakan dilaksanakan di lapangan SDN. 12 Api-Api Kec. Bayang. Tahap pelaksanan dilakukan scenario pembelajaran yang telah direncanakan dalam RPP. Materi pada pelaksanaan tindakan siklus I , implementasinya sebagai berikut: (1) Kegiatan Awal, guru menyiapkan peralatan / media pembelajaran, setting letak dan alat, guru menyiapkan pertanyaan-pertanyaan untuk mengelaborasi respon siswa, peneliti dan guru menyiapkan siswa dengan memulai proses pembelajaran dengan berdoa kemudian mempresensi, guru memberikan apersepsi, motivasi, penjelasan tujuan pembelajaran dan indikator yang harus dicapai, melakukan pemanasan. Melakukan pemanasan dengan permainan yang mengacu pada materi yang akan dipelajari, yaitu dengan bermain Kucingan dengan menggunakan bola. (2) Kegiatan Inti. Teknik Dasar Passing Bawah Menggunakan Bola voli Guru menjelaskan cara melakukan gerakan passing bawah bola voli menggunakan bola voli yang terdiri dari sikap permulaan, sikap saat perkenaan bola, serta sikap akhir yang benar. Siswa melakukan passing bawah dengan posisi berdiri, dilakukan secara bergantian. Satu siswa sebagai pengumpan yang nanti bergilir sebagai pemassing. Teknik Passing Bawah Bola Voli dengan permainan bola berantai Bola plastik bergabus ditali dengan rafia dan digantung pada net, ketinggiannya disesuaikan dengan tinggi siswa. Siswa mempassing bola dengan passing bawah secara berantai dari awal sampai yang paling akhir secara kontiyu. Guru menjelaskan cara melakukan gerakan passing bawah bola plastik bergabus, kemudian siswa mempraktikkanya diselingi istirahat 5 menit untuk merefleksikan pikiran.(3) Penutup. Melaksanakan pendinginan, evaluasi dan tanya-jawab mengenai pembelajaran yang telah dilakukan, siswa berdoa kemudian masuk kelas untuk menjawab soal yang telah dipelajari selama proses pembelajaran.

\section{c. Observasi}

Pengamatan dilakukan oleh peneliti bersama kolaborator saat proses pembelajaran berlangsung.Pengamatan dilakukan menggunakan lembar observasi keterampilan siswa dalam melakukan passing bawah dengan memperhatikan 3 ranah penilaian, yaitu kognitif, afektif dan psikomotorik. Hasil observasi tersebut adalah : (1) Proses tindakan, pertemuan Pertama pembelajaran passing bawah bola voli berjalan cukup baik. Guru sudah menyampaikan materi dan memberi contoh. Namun masih banyak siswa yang gerakannya masih salah. (2) Pengaruh, pembelajaran dengan memodifikasi permainan ternyata dapat mempermudah dan mengurangi rasa takut siswa terhadap passing bawah. Perbaikan-perbaikan gerakan mulai bisa diamati menjadi lebih baik meskipun belum semuanya mengalami peningkatan. (3) Kendala, dalam implementasi tindakan Ada beberapa kendala yang dihadapi ketika pelaksanaan tindakan. Pada pertemuan pertama, siswa masih sulit diatur di awal kegiatan. Konsentrasi siswa terkadang tidak fokus, masih terdapat siswa yang tidak memperhatikan perintah atau petunjuk-petunjuk dalam melakukan passing bawah. Ada beberapa siswa yang melakukan pembelajaran sesukanya sendiri, tidak sesuai dengan contoh yang diberikan oleh peneliti. Pembelajaran passing bawah bola voli masih belum terlaksana seperti yang diharapkan. (4) Identifikasi penyebab terkendalanya tindakan. Kendala yang dihadapi dapat diidentifikasi penyebabnya, terlalu banyaknya jumlah siswa kelas IV SDN. 12 Api-Api Kec. Bayang yaitu 41 siswa. Selain itu saat pembelajaran di sekitar lapangan bola voli desa Tengaran ada beberapa penjual mainan dan makanan, hal ini membuat siswa tidak fokus, memperhatikan pembelajaran. Kendala dalam pelaksanaan pembelajaran karena belum sepenuhnya perhatian siswa tertuju pada pembelajaran dan kurang serius dalam mengikuti pembelajaran. 
d. Refleksi

Berdasarkan hasil observasi pada tindakan pertama tersebut, peneliti melakukan analisis dan refleksi terjadi peningkatan.

\section{2) Siklus II}

Siklus II merupakan tindak lanjut dari hasil analisis dan refleksi siklus I, dimana dalam pelaksanaan tindakan siklus I rata-rata siswa menunjukan hasil yang kurang maksimal dan belum sesuai dengan kriteria yang telah ditetapkan. Pelaksanaan siklus II mengacu pada pelaksanaan siklus I, karena merupakan perbaikan dari siklus I. Adapun tahap yang dilakukan pada siklus II ini yaitu:

\section{a. Perencanaan}

Perencanaan tindakan, sebagai berikut: (1) Peneliti membuat rencana pelaksanaan pembelajaran (RPP) dengan mengacu pada tindakan yang diterapkan dalam PTK dan berdasarkan apa yang telah terjadi pada siklus I. (2) Menyiapkan modifikasi permainan yang lebih menarik dan mudah dilaksanakan untuk membantu pembelajaran passing bawah bola voli yaitu dengan menambahkan tanda dibawah bola gantung untuk posisi kaki pada waktu melakukan passing. (3) Menyusun instrument tes passing bawah dan lembar observasi atau pengamatan pembelajaran yang dicantumkan dalam rubric penilaian dalam RPP.

\section{b. Pelaksanaan}

Pelaksanaan tindakan siklus II dilaksanakan di lapangan bola voli SDN 12 Api-Api. Tahap pelaksanaan dilakukan dengan melaksanakan skenario pembelajaran yang telah direncanakan dalam RPP. Materi pada pelaksanaan tindakan siklus II, implementasinya sebagai berikut: (1) Kegiatan awal, Guru menyiapkan peralatan / media pembelajaran, setting letak dan alat yang dibantu oleh para peserta didik, Guru menyiapkan pertanyaan-pertanyaan untuk mengelaborasi respon siswa, Peneliti menyiapkan siswa dengan memulai proses pembelajaran dengan berdoa kemudian presensi, guru memberikan apersepsi, motivasi, penjelasan tujuan pembelajaran dan indikator yang harus dicapai, Melakukan pemanasan. Pemanasan yang diberikan berupa penguluran dan juga pemanasan dalam bentuk permainan. Peserta didik dibagi menjadi 3 kelompok, setiap kelompok membentuk lingkaran diambil salah satu siswa sebagai kucing. Tugas siswa yang membentuk lingkaran adalah melempar bola dari bawah seperti gerakan passing bawah kepada teman lain, jangan sampai bola ditangkap kucing. Jika bola ditangkap kucing, maka ia yang menggatikannya sebagai kucing, begitu dan seterusnya. (2)Kegiatan Inti. Gerak Dasar Passing Bawah Bola voli, guru menjelaskan cara melakukan gerakan passing bawah bola voli menggunakan bola voli yang terdiri dari sikap permulaan, sikap saat perkenaan bola, serta sikap akhir yang benar. Siswa melakukan passing bawah dari gerakan awal hingga akhir dalam posisi berdiri, dilakukan secara bergantian. Satu siswa sebagai pengumpan yang nanti bergilir sebagai pemassing. Passing Bawah Bola voli melalui permainan bola berantai. Guru menjelaskan cara melakukan gerakan passing bawah bola voli menggunakan bola plastik bergabus yang digantung dengan rafia sedangkan di bawah diberi tanda dengan kun untuk posisi kaki dengan benar dan memberikan contoh gerakan, kemudian peserta didik mempraktikkan passing individu dengan permainan bola berantai, dimana siswa memukul bola baergantian secara kontinyu sampai yang paling akhir.

c. Penutup

(a) Membariskan siswa dan melakukan pendinginan. (b) Evaluasi dan tanyajawab mengenai pembelajaran yang telah dilakukan. (c) Siswa berdoa kemudian masuk kelas untuk menjawab soal yang telah dipelajari selama proses pembelajaran.

\section{d. Observasi}

Pengamatan dilakukan oleh peneliti bersama kolaborator saat proses pembelajaran berlangsung.Pengamatan dilakukan menggunakan lembar observasi keterampilan siswa dalam melakukan passing bawah dengan memperhatikan 3 ranah penilaian, yaitu kognitif, afektif dan psikomotorik. Hasil observasi tersebut adalah : (a) Proses tindakan. Pertemuan pada siklus II proses tindakan telah berjalan dengan lancar. Guru menyampaikan materi dengan baik. Peserta didik juga dapat dikondisikan dengan baik. Pembelajaran berlangsung menarik dengan permainan bola berantai. Semua siswa mengikuti pembelajaran dari awal hingga akhir tindakan. Meski 
masih ada beberapa siswa putri yang kadang tidak serius melakukan passing bawah. Dari beberapa siswa putri tersebut ada yang malu-malu, ada juga yang kurang percaya diri dan malu karena ditertawakan oleh siswa putra. Namun secara keseluruhan pelaksanaan siklus II berjalan dengan lancar. (b) Pengaruh tindakan. Passing bawah bola voli melalui modifikasi alat pembelajaran telah diamati dapat meningkatkan hasil belajar siswa. Selain psikomotor yang meningkat, afektif dan kognitif juga semakin baik. (c) Kendala dalam implementasi tindakan. Ada beberapa siswa putri yang malu-malu, kadang tidak serius melakukan passing bawah. (d) Identifikasi penyebab terkendalanya tindakan. Ada beberapa siswa laki-laki yang menertawakan saat siswa perempuan melakukan passing bawah.

e. Refleksi

Berdasarkan hasil observasi pada tindakan pertama tersebut, peneliti melakukan analisis dan refleksi bahwa terdapat peningkatan hasil belajar siswa tiap siklus.

\section{PEMBAHASAN}

1) Perbandingan Hasil Tindakan Siklus I ke Siklus II

\begin{tabular}{ccccc}
\hline Tindakan & \multicolumn{2}{c}{ Siswa Tuntas } & \multicolumn{2}{c}{ Siswa Tidak Tuntas } \\
\hline \multirow{2}{*}{ Siklus I } & Jumlah & Prosentase & Jumlah & Prosentase \\
\hline Siklus II & 18 & $75 \%$ & 6 & $25 \%$ \\
\hline
\end{tabular}

\section{2) Analisis Pembelajaran}

Pada siklus I hasil belajar siswa dalam melakukan pembelajaran passing bawah adalah sebagai berikut: Siswa yang telah mencapai KKM adalah 18 siswa dan yang belum tuntas adalah 6 siswa sehingga keberhasilan pada siklus I adalah yang tuntas $75 \%$ dan yang belum tuntas adalah $25 \%$. Sedangkan hasil belajar siswa pada siklus II adalah sebagai berikut: Siswa yang telah mencapai KKM adalah 21 siswa dan yang di bawah KKM adalah 3 siswa, sehingga keberhasilan pada siklus II adalah 87,5\% dan siswa yang belum tuntas 12,5\%. Dari siklus I yang prosentase ketuntasannya hanya $75 \%$ menjadi $87,5 \%$ berarti ketuntasan hasil belajar siswa mengalami kenaikan sebesar 12,5\%. Dengan demikian dapat dikatakan bahwa pembelajaran telah berhasil karena siswa yang tuntas telah melebihi $85,00 \%$ dari jumlah siswa.

\section{3) Simpulan Siklus Berdasarkan Hasil Belajar}

Berdasarkan nilai-nilai dari siklus I dan siklus II dapat disimpulkan untuk siklus I pembelajaran belum berhasil karena belum memenuhi standar ketuntasan belajar 85,00\% dari jumlah siswa keseluruhan baik dalam aspek kognitif, afektif maupun psikomotor. Pada siklus I pembelajaran sudah berjalan dengan baik, anak sudah antusias dalam pembelajaran akan tetapi siswa masih serius dalam mengikuti pembelajaran dan masih ada yang takut atau kurang percaya diri. Sedang pada siklus II nilai pembelajaran lebih meningkat karena adanya perbaikan dalam pembelajaran dan pemberian materi sehingga siswa mampu mencapai KKM lebih dari 85,00\%.

\section{4) Ketuntasan Belajar}

Pada siklus I prosentase ketuntasan pembelajaran yaitu $75 \%$ sedangkan pada siklus II mengalami paningkatan yang sangat tinggi yaitu mencapai $87,5 \%$. Dengan demikian pembelajaran dinyatakan tuntas dengan hasil labih rendah dari 85,00\% siswa sudah mencapai KKM dan tidak perlu lagi diadakan tindak selanjutnya.

\section{SIMPULAN DAN SARAN}

Hasil penelitian menunjukkan bahwa melalui modifikasi permainan bola berantai pada pembelajaran dapat meningkatkan hasil belajar passing bawah bola voli siswa SDN. 12 Api-Api Kec. Bayang. Hal ini ditunjukan dengan adanya peningkatan hasil belajar dari masing-masing aspek selama siklus I dan siklus II. Nilai psikomotor 
pada siklus I yang mencapai KKM sebanyak 58,83\%, sedangkan pada siklus II mencapai 83,3\%. Hasil penilaian Afektif selama siklus I sebanyak 70,83\% dan mengalami peningkatan pada siklus II menjadi $87,5 \%$. Sedangkan nilai kognitif selama siklus I sebanyak 79,16\% dan mengalami peningkatan pada siklus II menjasi 83,3\%. Dari hasil penelitian ini diharapkan guru dapat terus meningkatkan kualitas pembelajaran pendidikan jasmani dengan memberikan berbagai model pembelajaran dengan metode bermain agar siswa merasa tertarik pada olahraga yang sedang diajarkan guru dan juga tidak merasa jenuh atau takut.

Berdasarkan hal tersebut, maka dapat disampaikan beberapa saran antara lain sebagai berikut: (1) Pendekatan pembelajaran dengan bermain lebih menyenangkan buat siswa karena siswa tidak merasa berolahraga sebagaimana olahraga secara umumnya, dan setiap pembelajaran hendaknya disertai media penunjang yang memadai sehingga siswa lebih memahami materi yang sedang disampaikan. (2) Guru hendaknya terus berusaha untuk meningkatkan kemampuannya dalam mengembangkan materi, menyampaikan materi, serta dalam mengelola kelas, sehingga kualitas pembelajaran yang dilakukannya dapat terus meningkat seiring dengan peningkatan kemampuan yang dimilikinya. Selain itu, guru hendaknya mau membuka diri untuk menerima berbagai bentuk masukan, saran, dan kritikan agar dapat lebih memperbaiki kualitas mengajarnya. (3) Guru hendaknya dapat menerapkan metode yang tepat untuk menyampaikan materi pembelajaran. (4) Guru hendaknya kreatif dan inovatif dalam menyajikan materi dan memodifikasi peralatan yang digunakan dalam pembelajaran penjas.

\section{DAFTAR RUJUKAN}

Agus Kristiyanto. 2010. Penelitian Tindakan Kelas Dalam Pendidikan Jasmani dan Kepelatihan Olahraga Agus Mukholid. 2004. Pendidikan Jasmani. Surakarta : Yudistira

Aip Syarifuddin. 1993. Pendidikan Jasmani dan Kesehatan. Jakarta: Departemen Pendidikan dan Kebudayaan Amung Ma'mum \& Toto Subroto. 2001. Pendekatan Keterampilan Taktis Dalam Permainan Bolavoli Konsep \& Metode Pembelajaran. Jakarta : Depdiknas.

Aqip Zainal. 2008. Penelitian Tindakan Kelas : Untuk Guru SD, SDLB, dan TK. Bandung: CV Yrama Widya. Barbara L.V \& Bonnie J.V.1996. Bola Voli Tingkat Pemula. Alih Bahasa. Monti. Jakarta : RajaGrafindo.

Barseli, M., \& Ifdil, I. (2017). Konsep Stres Akademik Siswa. Jurnal Konseling dan Pendidikan, 5(3), 143-148. Dimyati dan Mudjiono. 2006. Belajar dan Pembelajaran. Dep. Pendidikan dan Kebudayaan.

IKAPI. 2009. Undang-Undang Sisdiknas (Sistem Pendidikan Nasional). Bandung: Fokusmedia.

M. Yunus. 1992. Bolavoli Olahraga Pilihan. Jakarta. Depdikbud Direktorat Jenderal PendidikanTinggi.

Mulyasa H.E. 2003. Kurikulum Berbasis Kompetensi. Remaja Rosda Karya: Bandung.

PBVSI. 1995. Metodologi Pelatihan. Jakarta. Sekertariat Umum PP. PBVSI.

Rusli Lutan. 1988. Belajar keterampilan Motorik Pengantar Teori dan Metode.

Jakarta: Depdikbud. Dirjendikti.

Samsudin. 2000. Pembelajaran Pendidikan JasmaniOlahraga dan Kesehatan SD. Jakarta: Prenada Media Grup. Soedarwo, Sunardi \& Agus Margono. 2000. Teori dan Praktek Bolavoli Dasar.

Suharno HP. 1985. Dasar-Dasar permainan Bolavoli. Yogyakarta : Percetakan Siliwangi.

Syamsir Aziz. 2005. Permainan Kecil Di SD. Jakarta : Universitas Terbuka

Taufik, T., \& Ifdil, I. (2013). Kondisi Stres Akademik Siswa SMA Negeri di Kota Padang. Jurnal Konseling dan Pendidikan, 1(2), 143-150.

Zola, N., Fadli, R. P., \& Ifdil, I. (2017). Chromotherapy to reducing stress. Open Science Framework. November, 20. 